\title{
ON THE SECTIONS OF INFERIOR OOLITE ON THE MIDFORD-CAMERTON SECTION OF THE LIMPLEY STOKE RAILWAY, SOMERSET.
}

\author{
By L. RICHARDSON, F.R.S.E., F.L.S., F.G.S.
}

(Read March sth, Igog.)

$\mathrm{T}$

$\mathrm{HE}$ Inferior Oolite has been exposed in several cuttings on the section of the Limpley Stoke and Camerton Line (G.W.R.) that lies between the latter place and Midford viaduct, but in only two-those quite close to Midford-were the sections at all satisfactory when I visited the neighbourhood.

As I have elsewhere shown*, between Bath and the Mendip Hills there are no Inferior-Oolite beds of earlier date than Garantiance hemera, which rest directly upon the Upper Lias. The deposits between the deposit of this date and the Fuller's Earth are, in descending order, (г.) the Rubbly Beds, (2.) Anabacia-Limestones, (3.) Doulting Stone, (4.) Upper Coral-Bed, and (5.) Dundry Freestone. The last-named has the most restricted geographical extent, being present at Dundry Hill, Timsbury Sleight, and for a small extent in the escarpment between Tunley and English Combe ; but absent from the neighbourhood of Midford. The Upper Coral-Bed is not well-developed over a large area, but as a sporadic deposit it is of considerable extent, being identifiable at such widely-separated localities as Cleeve Hill, near Cheltenham, and Radstock. The succeeding Doulting Stone and Anabacia-Limestones are very persistent over the region between the Mendip Hills and Bath; but the Rubbly Beds are subject to some variation in thickness. The three divisions, however, pass by degrees into the Clypeus-Grit of the Cheltenham district.

The two cuttings near Midford, already referred to, reveal the same rock-subdivisions, namely, Upper Trigonia-Grit, Upper CoralBed, and Doulting Stone, but in that farthest from Midford (and that is the third from the place where this line passes under the viaduct of the S. \& D. J. Railway-the first being in the Midford Sands) there is only a trace of the Doulting Beds remaining. Otherwise the sections in these two cuttings are similar, and a description of the one might well do for the other.

At the time of my visit (March, 1908) in company with the Rev. H. H. Winwood, F.G.S., the second cutting was not completed, and the western excavation resembled a quarry (Plate III, Fig. I); while the eastern half of the cutting was about finished.

* Quart. Journ. Geol. Soc., vol. 1xili (1907), pp. 383-444.

Proc. Geol. Assoc., Vol. XXI, PArt 2, I909.] 
Figure 2, Plate III, shows a more detailed view : at the base are the Midford Sands of the usual type; then follow the second and third beds -in descending order-of the Upper TrigoniaGrit ; which are succeeded by the magnificently-developed Upper Coral-Bed; that is in turn capped (as shown at the right-hand topcorner of the photograph) by the basal beds of the Doulting Stone.

In Figure 3, Plate III, is shown the top-bed of the Upper Trigonia-Grit, with the Upper Coral-Bed above it. The latter is in turn succeeded by the bottom-bed of the Doulting Stone, which is shown at the top of the photograph.

Figure 4, Plate III, shows the upper portion of the Upper CoralBed, and such of the Doulting Beds as have not betn removed by denudation. The photograph illustrates very clearly the massive character of the Doulting Stone beds and their way of breaking up.

The following is the section that was afforded in this second cutting from the place where the line passes under the Midford Viaduct.

\section{SECTION IN THE SECOND CUTTING ON THE CAMERTON LINE WEST OF MIDFORD VIADUCT.}

III. Doulting Stone. Limestone, broken up and much limewashed: seen, about

Limestone, massive; bored by annelids and Lithophagi at the top

Thickness in tt. in.

\section{Upper Coral- Bed (1 3 ft.).}

Non-sequence.

a. Limestone, whitish, rubbly, mixed with greyish-green marl; Isastrcea, very abundant, and in very large masses; Montlivaltia sp., Gresslya sp., Amberleya hiudlestoni, Richardson, Tereiratula (probably) glohata, auctt. non Sowerby, Lima (Plagiostoma) $\mathrm{sp}$. indet.

VI. Upper 7rigonia- a. Ragstone, brown, finely-ironshot, shelly ; Grit ( $9 \mathrm{ft} .7 \mathrm{in}$ ). the top portion is slightly bored, and there are a few oysters on the upper surface; Pleurotomaria, Trigonia costata (Sowerby), Ostrea, Pleuromy'a decurtata (Phillips), Serpula sp., Natica bajociensis, d'Orbigny, etc.; but all rare.

a. Ragstone, more shelly than bed $a^{*}$; Trichites (fragments) Astarte cf. elegans, Sow., Trigonia costata (Sowerby), Amm nites (Garantiana) Garantiantss, d'Orbigny : average . $. \quad \cdot .$.

6. Ragstone, similar to $a$, but yet more fossiliferous; Rhynchonella hampenensis, S. S. Buckman, Acanthothyris spinosa (Schlotheim), Pecten (Sincyclonema) demissus, Phillips, Pteria digttata (Deslongchamps), Ammonites (leriphinctes) funatus, Oppel†-" a form common in the Garantiana-Beds of Dorset" (S. S. Buckman) . . . . .

† Ammonitcs triplicatus, Quenstedt (teste S. S. Buckman).

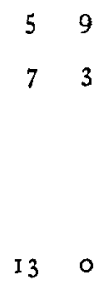


Proc. Geol. Assoc., Vol. XXI.

Plate III.

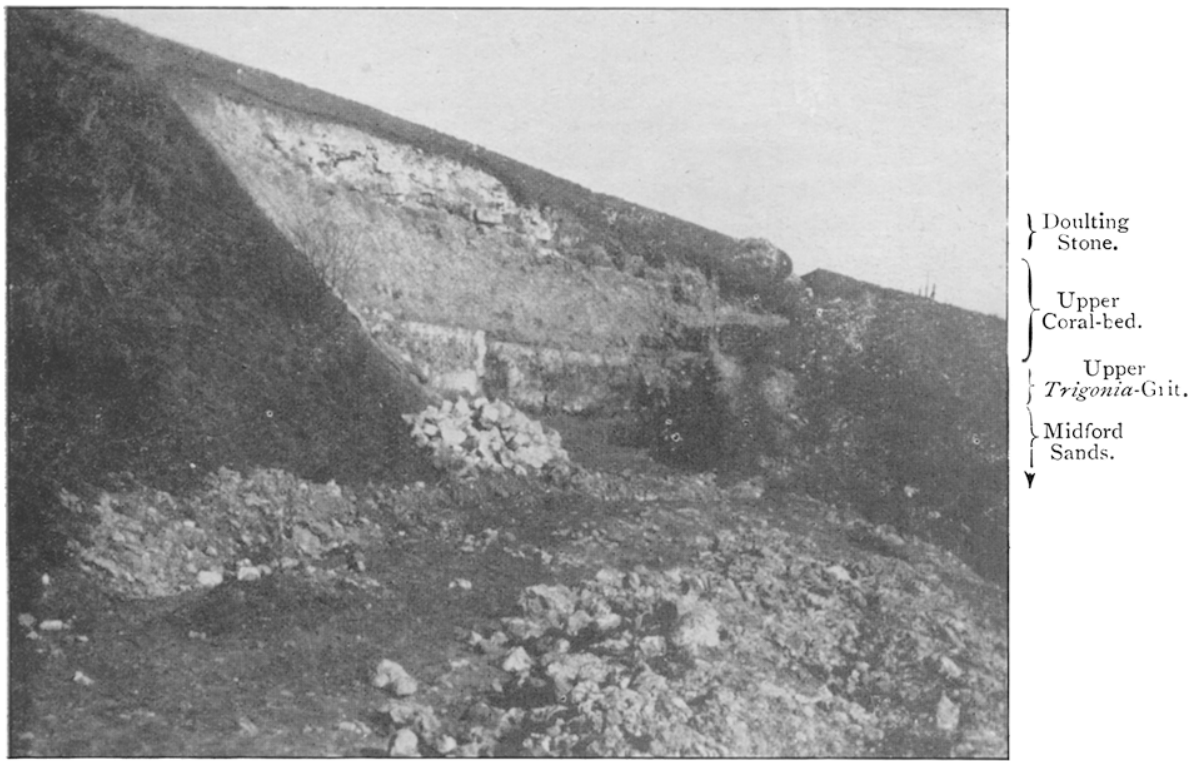

(Photo by G. J. Grey.

Fig. I.-View of the Unfinished Western End of the Second Cutting. (Block lent by the Somersetshire Arch. Soc.)

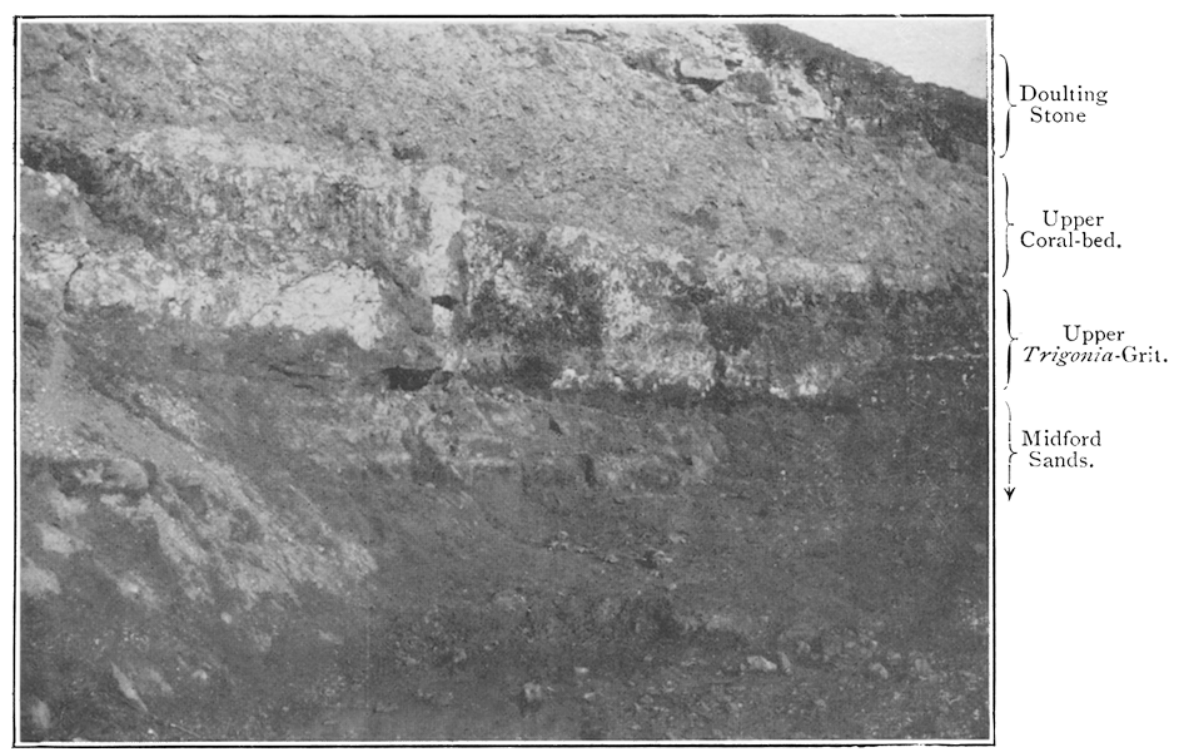

[Ploto by G. J. Grey.

Fig. 2.-More Detalled View of a poktion of the Section Shown in Fig. I. 
Proc. Geol. Assoc., Vol. XXI.

Plate III.

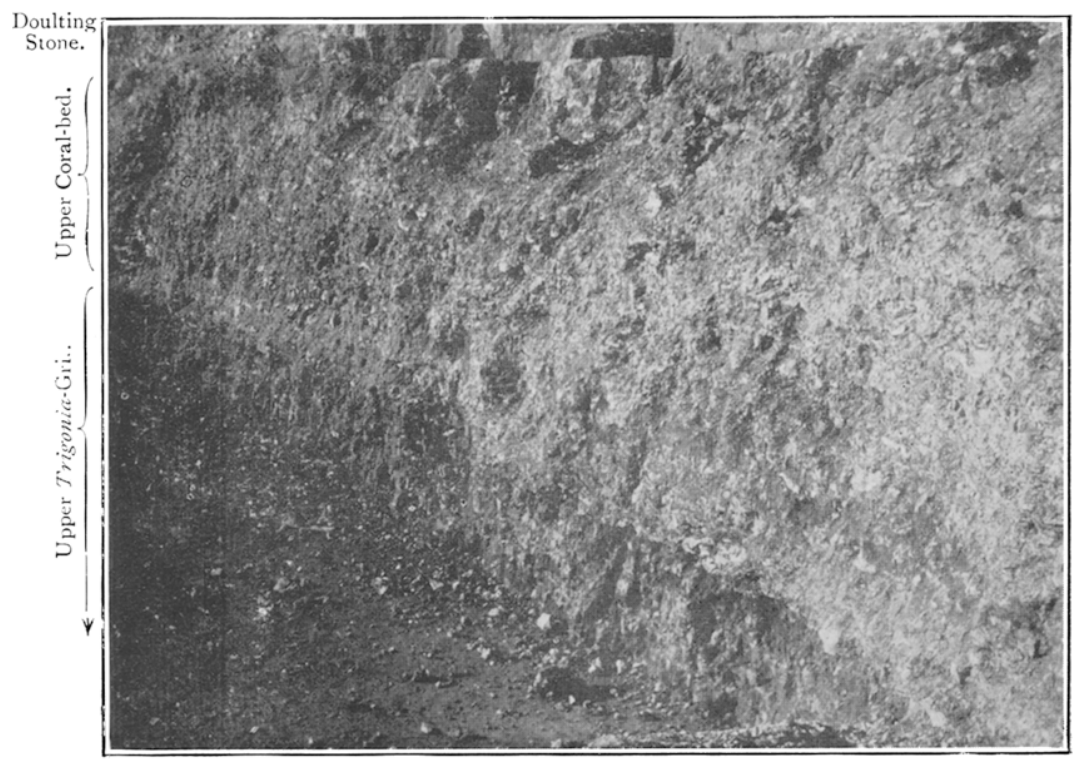

[Photo by G. J. Grey.

FIG 3.-VIEW OF THE TOP PORTION OF THE UPPER Trigonin-GRIT, UPIER Coral-bed, and Base of the Doulting Stone.

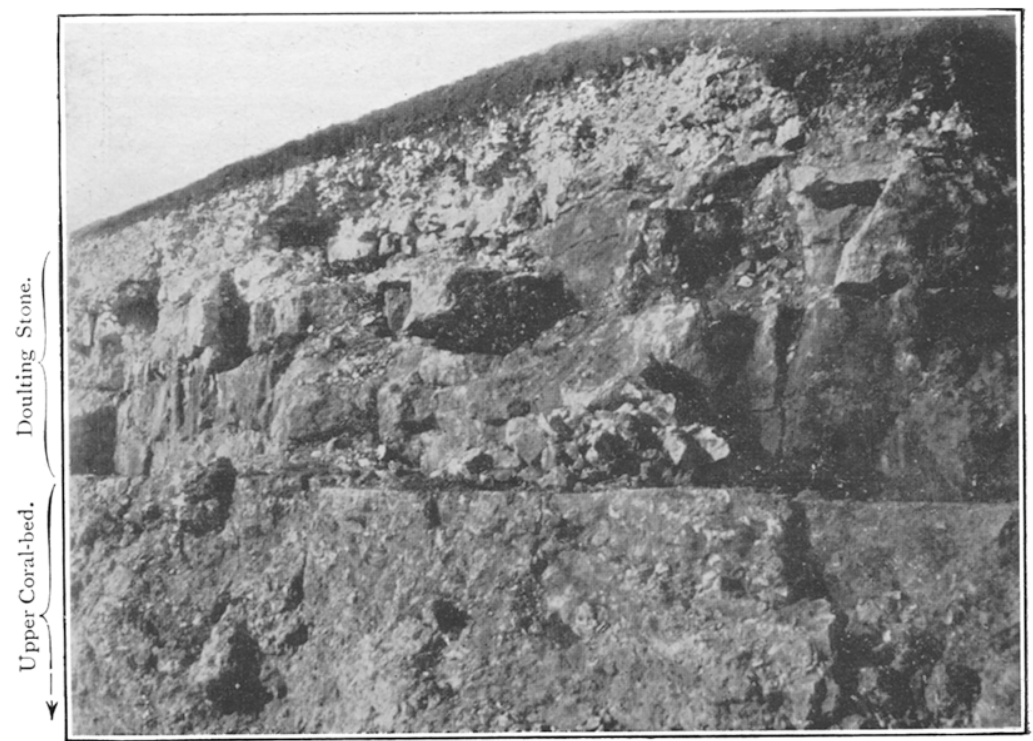

[Photo by G.J. Grey.

Fig. + - View of tha Upper Coral-bed and Doulting Stone. 
Non-sequence.
Midford
Sands.

The top-portion of the Midford Sands is a bed of hard sandstone that is conjoined on to the Upper Trigonia-Grit bed above. Below are the usual Midford Sands, yellow, micaceous, and rather indurated: seen .

Taking the beds in ascending order, there is no comment to make on the Midford Sands; they are of the usual type. The hard bed at their top is remarkably interwoven, as it were, into the superincumbent Upper Trigonia-Grit, which-at its base-is noticeably conglomeratic. The pebbles are of various kinds of rock, and the portion containing them very closely resembles the well-known Maes-Knoll Conglomerate-Bed.

The Upper Trigonia-Grit here is thicker than in the mainroad section alongside the southern end of the Midford Viaduct by $4 \mathrm{ft}$. 7 ins. ; and a similar comparison between the thickness of the Upper Coral-Bed shows an increase in that of the railwaycutting by $5 \mathrm{ft}$. Indeed, I have nowhere seen a better development of this most interesting deposit.

Above the Upper Coral-Bed comes the Doulting Stone. The whole of this sub-division is not present, for the top-portion has been removed by denudation, and there are, therefore, no traces of the Anabacia-Limestones.

The Doulting Stone in the Midford road-side section attains a thickness of I I ft. 9 ins.

As the Anabacia-Limestones are not present in the "second" railway-cutting, I have obtained two photographs of the Midford main-road section. Fig. I, Pl. IV, shows the sequence from the Midford Sands, at the far end of the section and close to the roadlevel, through the Upper Trigonia-Grit, Upper Coral-Bed, and Doulting Stone, to the top-bed of this last sub-divisionthe very massive bed seen at the left-hand top corner of the picture. This top-bed is depicted again in fig. 2 of the same Plate, and above it are imperfectly exposed tire Anabacia-Limestones. The thin, hard bed $(b)$ there seen jutting out, is the stratum referred to in my paper as "a thin, well-marked limestoneband, in which the characteristic coral is very abundant; and being harder than the beds immediately above and below it, ... . stands out conspicuously in most of the sections. . .." (p. 408).

Returning now to the Camerton Line, the section in the third cutting, as already remarked, is very similar to that in the second.

Thence westwards the railway closely follows the old canal, passing under an artificial cliff of Midford Sands, that overlooked the canal, a short distance to the east of the Anchor Inn. The abandoned canal, drained dry, is now utilised for the stretch of railway which is situated to the north of Combe Hay, and the 
well-built canal-tunnel, constructed over a century ago, takes the line under the cross-roads a short distance west of the village.

At the western entrance to this tunnel is an artificial cliff composed of Doulting Stone, while the shallow cuttings between here and the Fcss Way are in the same sub-division.

On the eastern and western sides of the comb, at the mouth of which Dunkerton is situated and connected by a viaduct, there are cuttings. The rocks in both are very greatly disturbed, but débris of Doulting Stone predominates, although there are traces of the Upper Coral-Bed-in the large masses of Isastroea that are lying about-Upper Trigonia-Grit, and Midford Sands.

The remaining cuttings between here and Camerton are in the Lias, Rhætic and Keuper; but on the northern slope of that on the main line east of the Colliery (Dunkerton) are huge masses of Doulting Stone (with numerous imprints of fossils) that have slipped down the hill-side, and are indistinguishable at a distance from the yellow Liassic limestone of Jamesoni date-the local Marlstone, which is also present. The upper surfaces of these blocks of Marlstone are covered with belemnites, amongst which are scattered species of Cincta, Pleuromya, etc.

Since this paper was written, Mr. H. B. Woodward, F.R.S., has contributed to the "Summary of Progress of the Geological Survey" for rgo7, notes on "The New Great Western Branch Railway from Camerton to Limpley Stoke, Somerset" (pp. I 55$\mathrm{r} 57$ ), in which he gives an account of the principal section, but does not attempt any detailed correlation; and the Rev. H. H. Winwood has written on "The New Branch Linerof the G.W.R. from Camerton to Limpley Stoke." * He gives a picture of the "second cutting," and more stratigraphical details than Mr. Woodward.

- Proc. Bath and District Branch of the Scmersctshive Arct. and Na!. Hist. Soc., Igo8, pp. $195-197$. 
Proc. Geol. Assoc., Vol. XXI.

Plate IV.

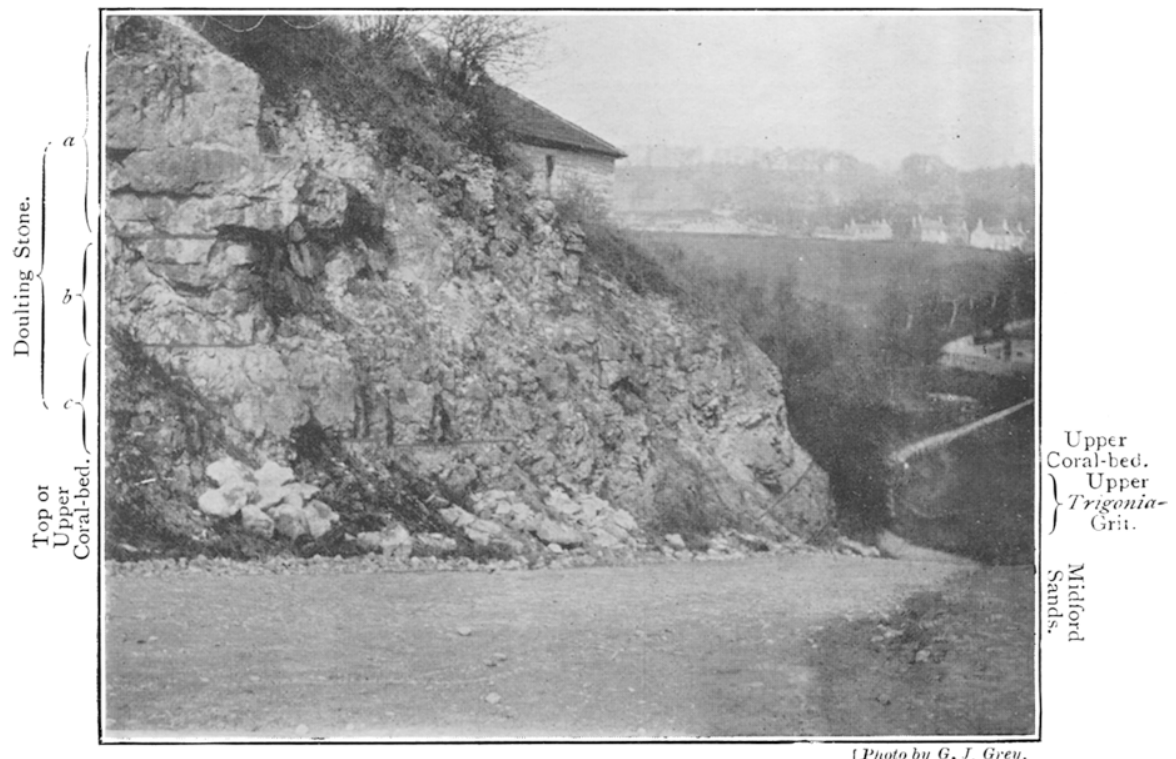

Fig. I.-Main-RoAd Section, Midford, Somerset.

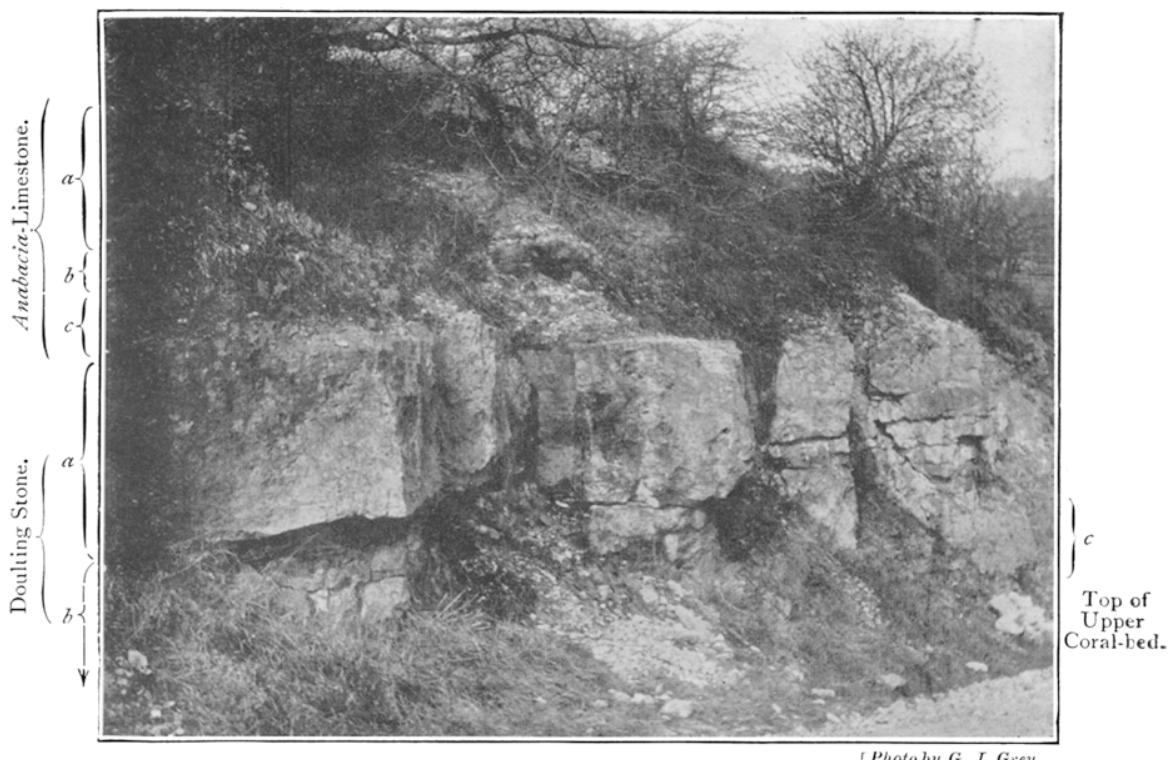

Fig. 2--Upper Portion of the Midford Main-Road Section. 